\title{
PRINSIP KEPASTIAN HUKUM TERHADAP PEMBATALAN AKTA PEJABAT PEMBUAT AKTA TANAH
}

\author{
Karuniawan Nurahmansyah \\ Pengacara, Konsultan Hukum dan Founder KN\&P Law Office Jember \\ Jember Jawa Timur \\ Email: Awanhansyah88@gmail.com
}

\begin{abstract}
Abstraks
Pembatalan akta PPAT oleh Pengadilan, jika tidak ada cacat hukum atas akta PPAT tersebut maka tidak akan terjadi pembatalan akta tersebut, akan tetapi dalam menjalankan tugas dan kewajibannya sebagai PPAT tidak menutup kemungkinan produk hukum yang dibuatnya dapat dibatalkan. Sebagai fakta hukum yang terjadi pada Pengadilan Negeri Surakarta Putusan Nomor : 20/Pdt.G/2013/PN.Ska dan yang kedua Putusan Nomor 06 / PDT / 2014 / PTY, yang terjadi pembatalan oleh pengadilan dikarena produk hukum yang dibuat oleh PPAT terjadi perbuatan melanggar hukum, titik fokus terhadap penelitian ini adalah adanya perbuatan melawan hukum yang dilakukan oleh PPAT serta akta yang dibuat oleh PPAT dinyatakan batal demi hukum oleh Mahkamah Agung, pada hal tersebut dikarenakan cacat hukum didalam pembuatan akta otentik tersebut, maka terhadap pembatalan pada PPAT tersebut penulis akan melakukan penelahaan dan akan mencoba untuk memahami dan menguraikan lebih lanjut mengenai akta PPAT yang dibatalkan oleh Mahkamah Agung Republik Indonesia.
\end{abstract}

Kata Kunci : Prinsip Kepastian Hukum, Pembatalan Akta PPAT.

\begin{abstract}
The cancellation of PPAT certificate, if there was no blemish law for the PPAT certificate there shall not be any the cancellation of the certificate, but their duty and their obligations as PPAT does not preclude the possibility he made a legal product that can be undone. As a fact law that occurs in the district court decisions Surakarta No. 20/Pdt.g2013/PN.SKA decisions and the second Yogyakarta No.06/pdt/2014/PTY, that occurs the cancellation of by a court dikarena a legal product that made by ppat happened unlawful act, A focal point to the research is the existence of an unlawful act carried out by ppat as well as deed made by PPAT declared null and void by the supreme court, on the law were due to defects in the manufacture of such authentic deed, as for the cancellation on ppat the writer would do and will try to understand and outlines more about PPAT certificate canceled by the supreme court Republic Of Indonesia.
\end{abstract}

Keywords: Legal Protection, Criminal Act, Crime of Motorized. 


\section{PENDAHULUAN}

\section{A. Latar Belakang}

Pembangunan bangsa selama ini dengan sistem sentralistik dan top down oleh banyak kalangan dipandang sebagai sistem yang telah menciptakan kegagalan dan ketergantungan bagi masyarakat terhadap pemerintah. ${ }^{1}$ Pada Pasal 1 Peraturan Pemerintah Republik Indonesia Nomor 24 Tahun 2016 Tentang Perubahan Atas Peraturan Pemerintah Nomor 37 Tahun 1998 Tentang Peraturan Jabatan Pejabat Pembuat Akta Tanah yang selanjutnya disebut PP 24/2016 menyebutkan bahwa "Pejabat Pembuat Akta Tanah, adalah pejabat umum yang diberi kewenangan untuk membuat akta-akta otentik mengenai perbuatan hukum tertentu mengenai hak atas tanah atau Hak Milik Atas Satuan Rumah Susun."

Terkait itu Undang - Undang Nomor No 5 Tahun 1960 Tentang Peraturan Dasar Pokok - Pokok Agraria (selanjutnya disebut UUPA) telah memerintahkan kepada pemerintah untuk melaksanakan pendaftaran tanah dalam rangka menjamin kepastian hukum serta hak - hak atas tanah. ${ }^{2}$ Pendaftaran Tanah adalah rangkaian kegiatan yang dilakukan oleh pemerintah secara terus - menerus, berkesinambungan dan teratur, meliputi pengumpulan, pengolahan, pembukuan dan penyajian serta pemeliharaan data fisik dan data yuridis, dalam bentuk peta dan daftar mengenai bidang-bidang tanah dan satuan-satuan rumah susun. ${ }^{3}$

Pendaftaran tanah di Indonesia pada era globalisasi sekarang sangat penting karena jaminan kepastian hukum bukan hanya dimaksudkan untuk memastikan siapa pemilik tanah pada saat itu, akan tetapi termasuk pula perlindungan hukum bagi mereka yang akan memperoleh hak atas bidang tanah tersebut pada waktu yang akan datang. ${ }^{4}$ Sebelum melakukan pendftaran akta tanah maka langkah pertama ialah melakukan akta jual beli hak atas tanah sebagai bentuk perjanjian peralihan hak atas tanah yang meliputi akta perjanjian jual beli yang dibuat oleh PPAT, berlaku sebagai dasar hukum bagi pembeli untuk mengajukan perolehan hak atas tanah

${ }^{1}$ Syahrul Ibad, The Development Village Government In Synergity Of The Implementation In Law No. 6/2014, Jurnal Politico Vol. 20 No. 2 September 2020 Page: 113-124, DOI: https://doi.org/10.32528/politico.v20i2.3638

2 Herowati Poesoko, Parate Executi obyek Hak Tanggungan (inkonsistensi, konflik norma dan kesatuan penalaran dalam UUHT), ( Yogjakarta : Laksbang Pressindo, 2008), hlm 122

${ }^{3}$ Herlien Budiono, Kumpulan Tulisan Hukum Perdata DI Bidang Kenotariatan, (Bandung ; Citra Aditya Bakti, 2012 ), hlm 34

${ }^{4}$ Ibid, hlm 36

\section{HUKMY|Jurnal Hukum}


kepada BPN. 5 Secara normatif, jika tidak ada cacat hukum atas jual beli tanah itu maka pembeli dapat memperoleh hak atas tanah yang dikehendaki tersebut dan kepemilikan hak atas tanah tersebut tercatat di kantor pertanahan, selanjutnya pembeli akan mendapatkan sertipikat hak atas tanah, sebagai bukti atas kepemilikannya itu.

Fakta hukum yang terjadi pada Pengadilan Negeri Surakarta Putusan Nomor : 20/Pdt.G/2013/PN.Ska, yang terjadi pada Soepojo sebagai penggugat melawan Giri Setiawan, Harti serta Notaris Sunarto sekaligus sebagai PPAT yang menjadi pihak yang tergugat. Yang pada intinya perkara yang terjadi ialah permasalahan obyek sengketa gono - gini yang terjadi pada pihak tergugat dan penggugat yaitu berupa tanah dan bagunan rumah yang berdiri diatas tanah hak milik nomor: 1167 atas nama Soepojo ,luas lebih kurang 263 M2 terletak di Jalan Kalingga VI nomor: 4 Kelurahan Kadipiro Kecamatan Banjarsari Kota Surakarta yang dibagi menjadi 2 bagian yanrg sama yaitu $1 / 2$ (setengah) sama rata.

Pada bulan September 2008 saudara Giri Setiawan bermaksud untuk meminjam sertifikat yang menjadi objek sengketa tersebut kepada Soepojo dengan maksud untuk menjaminkan sertifikat tersebut kepada Bank, kemudian diajak ke Notaris /PPAT Sunarto,S.H akan tetapi alangkah terkejutnya Soepojo ternyata pada bulan Oktober 2012, sertifikat tersebut telah dibalik nama atas nama Giri Setiawan dengan akta jual beli nomor : 372/Banjarsari/2008 yang dibuat oleh PPAT Sunarto S.H, maka pihak Soepojo melakukan gugatan pada Pengadilan Negeri Surakarta untuk membatalkan Akta PPAT yang dibuat oleh Suharto, S.H merupakan perbuatan melawan hukum.

Sebagai isu hukum selanjutnya yaitu yang terjadi, Pada Putusan Nomor 06/ PDT/ 2014/ PTY, antara Sri Widadi Sulistiningsi selaku Penggugat melawan Muhammad Syarif Hidayat, Maya Mexitalita, serta Maria Farnsisca Jenny Setiawan Yosgiarso Sebagi Notaris/PPAT yang selaku tergugat dan Turut tergugat Pimpinan Kantor Cabang PT Bank Permata Tbk, serta turut tergugat Agung Tri Hartanto. Yang pada intinya adalah Bahwa dengan adanya keyakinan dari Para Penggugat terhadap

${ }^{5}$ Ibid, hlm 37 
Tergugat I tidak akan menipu dan syarat yang dilakukan dihadapan notaris hanya formalitas, kemudian pada tanggal 28 Juni 2010 Para Penggugat diajak Tergugat I \&II untuk datang ke kantor Notaris - PPAT Maria Fransisca Jenny Setiawati Yosgiarso, S.H, untuk melakukan jual beli atas SHM No.02546 atas nama Ir. Agung Tri Hartanto dengan Akta Jual Beli No. 58/2010 dan Sertifikat Hak Milik No. 02547 atas nama Ir. Agung Tri Hartanto dengan Akta Jual beli No 59/2010 maka akta tersebut merupakan perbuatan melawan hukum.

Terkait akta yang dibuat oleh PPAT dinyatakan batal demi hukum oleh Mahkamah Agung, pada hal tersebut dikarenakan cacat hukum didalam pembuatan akta otentik tersebut, maka terhadap pembatalan pada PPAT tersebut penulis akan melakukan penelahaan dan akan mencoba untuk memahami dan menguraikan lebih lanjut mengenai akta PPAT yang dibatalkan oleh Mahkamah Agung Republik Indonesia. Berdasarkan uraian latar belakang masalah di atas, dengan ini penulis hendak melakukan pengkajian lebih mendalam mengenai terkait "Prinsip Kepastian Hukum Terhadap Pembatalan Akta Pejabat Pembuat Akta Tanah"

\section{B. Rumusan Masalah}

Berdasarkan latar belakang yang telah dikemukakan diatas, maka dapat diidentifikasikan masalah-masalah yang akan diteliti dan dianalisa adalah: Apakah akta pejabat pembuat akta tanah sudah memenuhi kualifikasi sebagai akta otentik sesuai dengan Pasal 1868 KUHPerdata? Apakah akta pejabat pembuat akta tanah dapat dibatalkan oleh pengadilan ? Bagaimanakah konsep pengaturan kedepan terhadap pembatalan akta pejabat pembuat akta tanah?

\section{Motode Penelitian}

Pada suatu penulisan harus mempergunakan metode penulisan yang tepat karena hal tersebut sangat diperlukan dan merupakan pedoman dalam rangka mengadakan analisis terhadap data hasil penelitian. Ciri dari karya ilmiah di bidang hukum adalah mengandung kesesuaian dan mengandung kebenaran yang dapat dipertanggung jawabkan. ${ }^{6}$

\footnotetext{
${ }^{6}$ Peter Mahmud Marzuki, Penelitian Hukum, Edisi Revisi Cetakan ke 9, (Jakarta : Kencana Prenada Media Group 2014). hlm. 60
}

186 HUKMY|Jurnal Hukum 
Tipe penelitian yang digunakan adalah Yuridis Normatif (Legal Research). Pengertian penelitian tipe Yuridis Normatif adalah penelitian yang dilakukan dengan mengkaji dan menganalisa substansi peraturan perundang-undangan, literaturliteratur yang bersifat konsep teoritis atas pokok permasalahan atau isu hukum dalam konsistensi dan kesesuaian dengan asas-asas dan norma hukum yang ada. ${ }^{7}$ Penulis dalam tesis ini mengunakan 3 (tiga) bentuk pendekatan masalah, yaitu pendekatan perundang-undang (statute approach), pendekatan konseptual (conceptual approach), dan pendekatan kasus (case approach) yang diuraikan sebagai berikut :

1. Pendekatan undang-undangan (Statute Approach), yaitu suatu pendekatan yang dilakukan dengan menelaah semua undang-undang dan regulasi yang tersangkut paut dengan isu hukum yang sedang dihadapi. ${ }^{8}$

2. Pendekatan Konseptual (conseptual approach), adalah pendekatan yang beranjak pada pandangan-pandangan dan doktrin-doktrin yang berkembang dari ilmu hukum, sehingga dengan mempelajari pandangan-pandangan dan doktrin yang berkembang dalam ilmu hukum, konsep-konsep hukum dan asasasas hukum yang relevan dengan isu hukum yang dihadapi. ${ }^{9}$

3. Pendekatan kasus (case approach) adalah suatu pendekatan yang mengkaji beberapa kasus untuk referensi bagi suatu isu hukum. Berbeda dengan penelitian sosial, pendekatan kasus dalam penelitian normatif bertujuan untuk mempelajari penerapan norma-norma atau kaidah hukum yang dilakukan dalam praktek hukum. Terutama mengenai kasus-kasus yang telah diputuskan sebagaimana yang dapat dilihat dalam yurisprudensi terhadap perkara-perkara yang menjadi fokus penelitian. ${ }^{10}$

Sedangkah bahan hukum primer yang digunakan penulis dalam penulisan tesis ini yang meliputi:

1. Burgelijk Wetbook (BW)

\footnotetext{
7 Peter Mahmud Marzuki, Penelitian Hukum, Edisi Revisi Cetakan ke 9, (Jakarta : Kencana Prenada Media Group 2014). hlm. 60

${ }^{8}$ Ibid, hlm 134

9 Ibid, hlm 135-136

${ }^{10}$ Herowati Poesoko, Op. Cit, hlm 38-39
} 
2. Undang - Undang Nomor No 5 Tahun 1960 Tentang Peraturan Dasar Pokok Pokok Agraria

3. Undang-Undang Nomor 2 Tahun 2014 Tentang Perubahan Atas UndangUndang Nomor 30 Tahun 2004 Tentang Jabatan Notaris.

4. Peraturan Menteri Negara Agraria/ Kepala Badan Pertanahan Nasional Nomor 3 Tahun 1997 Tentang Ketentuan Pelaksanaan Peraturan Pemerintah Nomor 24 Tahun 1997 Tentang Pendaftaran Tanah.

5. Peraturan Pemerintah Republik Indonesia Nomor 24 Tahun 2016 Tentang Perubahan Atas Peraturan Pemerintah Nomor 37 Tahun 1998 Tentang Peraturan Jabatan Pejabat Pembuat Akta Tanah.

Bahan hukum sekunder berupa semua publikasi tentang hukum yang bukan merupakan dokumen-dokumen resmi. Publikasi tentang hukum meliputi buku-buku teks hukum, kamus-kamus hukum, dan jurnal-jurnal hukum, bahan - bahan cetakan (print out). ${ }^{11}$ Pertama, mengidentifikasi fakta hukum dan mengeliminir hal-hal yang tidak relevan untuk menetapkan isu hukum yang hendak dipecahkan; Kedua, pengumpulan bahan-bahan hukum dan sekiranya dipandang mempunyai relevansi juga bahan-bahan non hukum; Ketiga, melakukan telaah atas isu hukum yang diajukan berdasarkan bahan-bahan yang telah dikumpulkan; keempat, menarik kesimpulan dalam bentuk argumentasi yang menjawab isu hukum; dan yang kelima, memberikan preskripsi berdasarkan argumentasi yang telah dibangun di dalam kesimpulan. ${ }^{12}$ Kemudian langkah-langkah selanjutnya yang dipergunakan dalam suatu penelitian hukum adalah melakukan telaah atas isu hukum yang telah dirumuskan dalam rumusan masalah untuk menarik kesimpulan berdasarkan bahan-bahan hukum.

\section{PEMBAHASAN}

\section{Akta Pejabat Pembuat Akta Tanah Sebagai Akta Otentik Sesuai Pada Pasal 1868 KUHPerdata}

11 Ibid. hlm 87

12 Peter Mahmud Marzuki. Op.Cit hlm. 213.

188 HUKMY|Jurnal Hukum 
Pada pasal 1867 KUHperdata disebutkan ada istilah Akta otentik, serta pada pasal 1868 KUHPerdata memberikan batasan unsur yang dimaksud dengan akta otentik yaitu: ${ }^{13}$

1. Akta itu harus dibuat oleh atau dihadapan seorang pejabat umum.

2. Akta itu harus dibuat dalam bentuk yang ditentukan oleh undang - undang

3. Pegawai umum / pejabat umum oleh atau dihadapan siapa itu dibuat, harus mempunyai kewenangan untuk membuat akat tersebut.

Dengan demikian akta otentik PPAT sudah memenuhi kualifikasi sebagai akta otentik sesuai dengan Pasal 1868 kuhperdata yang diberikan kepada pejabat tertentu yang dikualifikasikan sebagai pejabat umum, seperti akta otentik tidak dibuat oleh notaris saja melainkan PPAT juga serta pejabat lelang dan pegawai kantor catatan sipil.

\section{a. Karakteristik akta pejabat pembuat akta tanah.}

Karakteristik pada akta PPAT juga dapat dilihat pada bentuk isi akta, Habib Adjie menjelaskan pada karakteristik akta PPAT meliputi :14

1. Kepala Akta, terdiri atas keterangan-keterangan dari PPAT mengenai dirinya sendiri serta orang-orang yang datang menghadapnya.

2. Badan Akta, terdiri atas keterangan-keterangan yang diberikan oleh para pihakpihak yang pada aktanya atas permintaan yang bersangkutan serta dituangkan pada bentuk akta.

3. Penutup Akta, terdiri atas keterangan dari PPAT mengenai waktu dan tempat akta dibuat, selanjutnya berisi keterangan mengenai saksi-saksi, dan pada bagian akhir tentang pembacaan serta penandatanganan dari akta itu.

Sedangkan Pasal 1868 KUHperdata menyebutkan bahwa akta autentik adalah suatu akta yang di dalam bentuk yang ditentukan oleh Undang-Undang, dibuat oleh atau dihadapan pejabat yang berwenang untuk itu, ditempat dimana akta itu dibuatnya. Maka sesuai Pasal 1868 KUHPerdata syarat komulatif yang harus dipenuhi untuk dapat dikategorikan sebagai akta autentik notaries.

\footnotetext{
${ }^{13}$ Habib adjie, Op.Cit, hlm 7

14 Ibid, hlm 78
} 


\section{b. Syarat formal akta pejabat pembuat akta tanah}

Syarat sahnya perjanjian pada pasal 1320 KUHPerdata, apabila dikaitkan dengan teori kepastian hukum merupakan suatu perjanjian tidak dapat dibatalkan oleh PPAT dikarenakan bentuk pembatalan akta tersebut para pihak yang membatalkan serta dapat dilakukan oleh hakim dengan dasar permohonan dari pihak dalam perjanjian, mendasarkan pada bentuk kepastian hukum yang tertuang dalam ketentuan Pasal 1320 KUHPerdata. ${ }^{15}$

Terkait pada akta pejabat pembuat akta tanah sebagai pemenuhan kualifikasi akta otentik sesuai pada Pasal 1868 KUHPerdata dan karakteristik akta pejabat pembuat akta tanah serta syarat formal akta pejabat pembuat akta tanah terdapat asasasas fundamental yang melingkupi hukum kontrak ialah ${ }^{16}$

1. Asas Konsensualisme, bahwa perjanjian terbentuk karena adanya perjumpaan kehendak (consensus) dari pihak-pihak.

2. Asas kekuatan mengikat perjanjian (verbindende kracht der overeenkomst), bahwa para pihak harus memenuhi apa yang mereka sepakati pada perjanjian yang mereka buat.

3. Asas kebebasan berkontrak (contractsvrijheid), bahwa para pihak menurut kehendak bebasnya masing-masing dapat membuat perjanjian dan setiap orang bebas mengikatkan diri dengan siapapun yang ia kehendaki. Pihak-pihak juga dapat menentukan cakupan isi serta persyaratan dari suatu perjanjian dengan ketentuan bahwa perjanjian tersebut tidak boleh bertentangan dengan peraturan perundang-undangan yang bersifat memaksa, baik ketertiban umum ataupun kesusilaan.

Sudikno Mertokusumo memberikan pengertian asas hukum sebagai suatu pikiran dasar yang bersifat umum yang melatarbelakangi pembentukan hukum positif. ${ }^{17}$ Dengan demikian asas hukum tersebut pada umumnya tidak tertuang di dalam peraturan yang konkret akan tetapi hanyalah merupakan.

\footnotetext{
15 Herry Susanto, Peranan Notaris Dalam Menciptakan Kepatutan Dalam Berkontrak, (Yogyakarta, FH UII Press ,2010), hlm.91

${ }^{16}$ Herlien Budiono, Asas Keseimbangan Bagi Hukum Perjanjian Indonesia (Hukum Perjanjian Berlandaskan Asas-Asas Wigati Indonesia), (PT.Citra Aditya Bakti, Bandung, 2006), hlm.94-95

17 Sudikno Mertokusumo, Mengenal Hukum (Suatu Pengantar), (Yogyakarta, Liberty, 2005), hlm.33
} 


\section{Pembatalan Akta Pejabat Pembuat Akta Tanah Oleh Pengadilan}

Pembatalan pada akta PPAT melalui putusan pengadilan, bukan hanya karena akibat dari kesalahan atau kelalaian pada PPAT saja saat membuat akta, akan tetapi pembatalan pada akta PPAT juga dapat disebabkan oleh kesalahan atau kelalaian para pihak yang saling mengikatkan diri pada akta tersebut, sehingga dengan adanya kesalahan atau kelalaian menyebabkan adanya gugatan dari salah satu pihak. ${ }^{18}$ Pada proses perdata, tidak jarang seorang PPAT berada pada kedudukan sebagai turut tergugat yang diberikan sebagai upaya yang dipaksakan, karena pada akta notariil khususnya Partij Acte yang kemudian menjadi alat bukti untuk perkara perdata.

Jika akta tersebut dapat dibuktikan dipersidangan, maka ada salah satu aspek yang menyebabkan cacatnya akta, sehingga akta tersebut dapat menjadi akta yang terdegradasi atau akta dibawah tangan, bahkan menjadi batal demi hukum. Berdasarkan Pasal 1870 KUHPerdata mengenai kekuatan pembuktian mengikat dan sempurna, suatu akta otentik yang mengikat berarti hakim terikat untuk percaya atas akta tersebut selama hal yang menjadi ketidakbenarannya tidak dapat dibuktikan, sedangkan maksud dari sempurna berarti sudah dianggap cukup sebagai alat bukti tanpa ada alat bukti lain. ${ }^{19}$

Dasar hukum pada pembatalan akta yang dibuat oleh Notaris / PPAT terkait pada jual beli tanah adalah merupakan perbuatan hukum, juga harus ditulis pada sebuah akta otentik. Akta otentik yang dibuat oleh Notaris / PPAT dan pada akhirnya dapat dibatalkan oleh Putusan Pengadilan, pembatalan akta dapat dikatakan sah apabila dalam melakukan pembuatan akta otentik terkait pada tanah tidak melakukan perbuatan melawan hukum, akan tetapi akta otentik dapat dikatakan tidak sah apabila melaukan perbuatan melawan hukum. Sebagai ilustrasi terkait akta yang dibuat Notaris/PPAT tidak sah ialah pada proses jual beli dilakukan berdasarkan pemaksaan oleh salah satu pihak, maka akta tersebut akan menjadi batal demi. Hal ini sesuai

\footnotetext{
${ }^{18}$ Habib Adjie, Kebatalan Dan Pembatalan Akta Notaris, (Bandung, PT Refika Aditama, 2011) hlm 68

19 Liliana Tedjosaputro, Etika Profesi Notaris dalam Penegakan Hukum Pidana,(Yogyakarta, PT. Bayu Indra Grafika, 2005) hlm 24
} 
dengan ketentuan Pasal 1320 KUHperdata, yang mana isi dari pada pasal tersebut adalah merupakan syarat-syarat sah peijanjian; yang isinya sebagai berikut : ${ }^{20}$

Pertama, Adanya kesepakatan dari mereka yang mengikatkan dirinya, maksudnya adalah bagi para pihak yang mengikatkan dirinya dalam suatu peijanjian harus ada kesepakatan atau setuju mengenai hal-hal yang pokok tentang peijanjian tersebut. Yang mana kesepakatan itu teijadi dengan tanpa adanya paksaan dari pihak manapun. Yang berarti bahwa kesepakatan itu teijadinya benar-benar dari keinginan para pihak yang mengikatkan dirinya di dalam suatu peijanjian Consensus atau kesepakatan merupakan langkah awal dari para pihak yang membuat peijanjian.

Kedua, Kecakapan untuk membuat suatu peijanjian, maksudnya adalah para pihak yang mengikatkan dirinya dalam suatu peijanjian haruslah orang-orang yang cakap membuat suatu peijanjian menurut hukum. Pada Pasal 1329 KUHperdata menyatakan bahwa setiap orang adalah cakap untuk membuat perikatan-perikatan, jika ia oleh undang-undang tidak dinyatakan tak cakap. Ada beberapa orang yang dipandang tidak cakap hukum didalam mengikatkan dirinya dalam suatu peijanjian. Sedangkan orang yang tidak cakap untuk membuat suatu peijanjian menurut Pasal 1330 KUHperdata yaitu: Pembatalan akta, Orang-orang yang belum dewasa, Mereka yang ditaruh dibawah pengampuan, Orang-orang perempuan, dalam hal-hal yang ditetapkan dalam undang - undang, dan pada umumnya semua orang kepada siapa undang-undang telah melarang membuat perjanjian tertentu

Ketiga, Suatu hal tertentu yang dapat diperjanjikan, maksudnya adalah bahwa di dalam perjanjian itu harus ada obyek yang diperjanjikan. Yang dimaksud obyek perjanjian adalah prestasi yang merupakan sesuatu yang harus dipenuhi oleh salah satu pihak kepada pihak lain. Dalam syarat ini, undang-undang menentukan bahwa hanya barang-barang yang dapat diperdagangkan saja yang dapat menjadi pokok perjanjian. Barang itu harus suatu barang yang paling sedikit dapat ditentukan jenisnya. Sebab apabila suatu obyek perjanjian tidak tertentu, maka perjanjian itu tidak sah.

Keempat, Suatu sebab yang tidak bertentangan dengan undang-undang, maksudnya adalah isi dan tujuan dari pada yang diperjanjikan didalam perjanjian

${ }^{20}$ Ridwan Indra R.A. Ragam Perjanjian di Indonesia. (Jakarta: CV. Trisula, 1996), hlm. 4 
tersebut tidak bertentangan dengan undang-undang atau dengan kesusilaan dan atau dengan ketertiban umum.

Berdasarkan uraian diatas, yang menyebabkan akta otentik dibatalkan adalah tidak adanya kesepakatan antara para pihak. Oleh karena melanggar Pasal 1320 KUHperdata, maka atas dasar itulah Pengadilan dapat memutuskan bahwa Akta Jual Beli yang dibuat di hadapan PPAT batal demi hukum.

\section{a. Kekuatan pembuktian pada akta ppat di pengadilan}

Akta PPAT sebagai akta otentik mempunyai kekuatan nilai pembuktian yang sepurna ada asas yang mendasari bahwa akta PPAT merupakan sebagai akta otentik yaitu, asas lahiriyah, asas formal, asas materil, maka akan penulis uraikan sebagai berikut :21

Pertama, Uitwendige Bewijskracht, Nilai pembuktian akta dari asas lahiriah, secara lahiriah tidak perlu dipertentangkan dengan alat bukti yang lainnya, jika ada yang menilai bahwa suatu akta PPAT tidak memenuhi syarat sebagai akta, maka yang bersangkutan wajib membuktikan bahwa akta tersebut secara lahiriah bukan akta otentik. Penyangkalan atau pengingkaran bahwa secara lahiriah akta Notaris, bukan sebagai akta otentik, maka penilaian pembuktiannya harus didasarkan kepada syaratsyarat akta Notaris sebagai akta otentik. Pembuktian semacam ini harus dilakukan melalui upaya gugatan ke pengadilan. Penggugat harus dapat membuktikan bahwa secara lahiriah akta yang menjadi objek gugatan bukan akta Notaris/PPAT.

Kedua, Formele Bewijskracht, Asas formal adalah bahwa akta PPAT harus memberikan kepastian bahwa suatu kejadian dan fakta tersebut pada akta betul-betul dilakukan oleh Notaris atau diterangkan oleh pihak-pihak yang menghadap pada saat yang tercantum pada akta sesuai dengan prosedur yang sudah ditentukan dalam pembuatan akta. Secara formal, untuk membuktikan kebenaran, dan kepastian tentang hari, tanggal, bulan, tahun, pukul (waktu) menghadap, dan para pihak yang menghadap, paraf dan tanda tangan para pihak/penghadap, saksi dan Notaris, serta membuktikan apa yang dilihat, disaksikan, didengar oleh Notaris dan mencatatkan keterangan atau pernyataan para pihak/pengahadap pada akta pihak.

\footnotetext{
${ }^{21}$ Subekti, Hukum Acara Perdata, ( Bandung ; Bina Cipta, 1989), hlm.93-94
} 
Ketiga, Materiele Bewijskrach, asas materiil menjelaskan bahwa kepastian tentang materi suatu akta sangat penting, bahwa pada akta merupakan pembuktian yang sah terhadap pihak-pihak yang membuat akta atau mereka yang mendapat hak dan berlaku umum, kecuali ada pembuktian sebaliknya. keterangan atau pernyataan yang dituangkan atau dimuat pada akta oejabat atau berita acara atau keterangan para pihak yang diberikan dihadapan Notaris/PPAT dan para pihak harus dinilai dengan benar. Jika akan membuktikan aspek materiil dari akta, maka yang bersangkutan harus dapat membuktikan bahwa Notaris tidak menerangkan atau menyatakan yang sebenarnya pada akta, atau para pihak yang telah benar berkata dihadapan Notaris menjadi tidak benar berkata, dan harus dilakukan pembuktian terbalik untuk menyangkal aspek materiil dari akta Notaris.

Dengan demikian ketiga asas yang telah diuraikan diatas merupakan kesempurnaan terhadap akta Notaris/PPAT sebagai akta otentik dan siapapun terikat oleh akta tersebut. Apabila dapat dibuktikan pada suatu persidangan pengadilan bahwa ada salah satu asas yang tidak benar atau kurang mencangkup asas diatas, maka akta itu hanya mempunyai kekuatan pembuktian sebagai akta dibawah tangan atau akta tersebut didegradasikan kekuatan pembuktiannya. ${ }^{22}$

\section{b. Bentuk Tanggungjawab PPAT Terhadap Akta yang dibatalkan Oleh Pengadilan}

Tanggungjawab PPAT secara perdata pada kebenaran materiil akta yang dibuatnya ialah pada konstruksi yuridis yang digunakan adalah konstruksi perbuatan melawan hukum, terdapat padal Pasal 1365 KUHPerdata yang pada intinya menjelaskan perbuatan melawan hukum meliputi adanya suatu perbuatan melawan hukum, adanya kesalahan dan adanya kerugian yang ditimbulkan, PPAT dapat dipertanggung jawabkan atas kebenaran materiil suatu aktanya apabila produk hukumnya yang diberikannya ternyata dikemudian hari merupakan suatu yang keliru atau dapat dikatakan perbuatan melawan hukum sesuai pada Pasal 1365KUHperdata, konstruksi pada UUJN tersebut dapat ditarik kesimpulan bahwa PPAT dapat dimintai pertanggungjawaban pada kebenaran materiil suatu akta yang dibuatnya ${ }^{23}$

\footnotetext{
22Paulus Effendi Lotulung, Perlindungan Hukum bagi Notaris Selaku Pejabat Umum dalam Menjalankan Tugasnya, (Bandung, Pradnya Paramita, 2003) hlm 87

23 Ima Erlie Yuana, Ruang Lingkup Kenotariatan, (Bandung ; Pradnya Paramitha, 2015) hlm 79
} 
Tanggungjawab PPAT mengenai ketentuan pidana tidak diatur didalam UUJN maupun di dalam Peraturan Jabatan Pejabat Pembuat Akta Tanah, namun tanggungjawab PPAT secara pidana dikenakan apabila melakukan perbuatan pidana yang melanggar hukum, Perkara pidana yang berkaitan dengan aspek formal akta PPAT, pihak penyidik, penuntut umum, dan hakim akan memasukkan Notaris/PPAT telah melakukan tindakan hukum maka dapat digunakan bentk tanggungjawab pidana sesuai dengan Pasal 263 ayat (1), (2) Pasal 264 KUHPidana :

Tanggungjawab PPAT secara adminitratif dapat dilihat pada ketentual pasal Pasal 85 Undang-Undang Jabatan Notaris, diatur juga mengenai sanksi bagi Notaris yang melanggar aspek formal tersebut, yaitu : Teguran lisan; Teguran tertulis; Pemberhentian sementara; Pemberhentian dengan hormat; Pemberhentian dengan tidak hormat. Dari beberapa sanksi yang akan dijatuhkan kepada Notaris/PPAT tersebut, yang termasuk sanksi administratif yaitu pemberhentian sementara, pemberhentian dengan hormat, dan pemberhentian dengan tidak hormat. Apabila dari uraian diatas bentuk tanggungjawab PPAT terhadap akta yang dibuatnya adalah bentuk tanggungjawab secara perdata, secara pidana dan secara adminitratif,

\section{c. Pertimbangan hakim ratio decidendi pada akta pejabat pembuat akta tanah dapat dibatalkan oleh pengadilan}

Tentang pertimbangan hukumnya bahwa dalam Putusan Pengadilan Negeri Surakarta 20/Pdt.G/2013/PN.Ska maka hakim menyatakan dan mengadili bahwa : Pertama, menyatakan Akta Jual beli No.372/Banjarsari/2008 yang dibuat oleh Notaris/PPAT Sunarto, SH (Tergugat III) tidak sah karena dibuat dengan melawan hukum yaitu tanah hak milik No.1167 atas nama Soepojo luas +263 m2 terletak di Kelurahan kadipiro, Kecamatan Banjarsari Kota Surakarta yang dijual belikan antara Tergugat I sebagai Pembeli dengan Penggugat sebagai Penjual tersebut yang masih dalam sengketa antara Penggugat dengan Tergugat II di Pengadilan Agama Surakarta dan proses jual belinya tidak melibatkan Tergugat II selaku salah satu pemilik tanah dan rumah tersebut; Kedua, menyatakan proses jual beli dengan Akta Jual Beli No.372/Banjarsari/2008 yang dibuat oleh Notaris/PPAT Sunarto, SH (Tergugat III) batal demi hukum karena dibuat dengan cara tidak sah dengan melawan hukum yaitu tanah hak milik No.1167 atas nama Soepojo luas + 263 m2 terletak di Kelurahan 
Kadipiro, Kecamatan Banjarsari, Kota Surakarta yang dijual belikan antara Tergugat I sebagai pembeli dengan Penggugat sebagai penjual tersebut yang masih dalam sengketa

Maka dapat dikesimpulkan bahwa AJB No.372/Banjarsari/2008 yang dibuat oleh Notaris.PPAT Sunarto, SH melanggar hukum serta Akta Jual Beli No.372/Banjarsari/2008 dinyatakan tidak sah batal demi hukum. Pada Kasus Posisi yang kedua yang terjadi pada Pengadilan Tinggi Yogyakarta Putusan Nomor 34/Pdt/2017/PT YYK, Yang terjadi antara Pada Putusan Nomor 06 / PDT / 2014 / PTY,

Menimbang, bahwa dengan hal demikian, maka pertimbangan-pertimbangan hukum Hakim Tingkat Pertama tersebut diambil alih dan dijadikan dasar didalam pertimbangan Putusan Pengadilan Tinggi sendiri, sehingga Putusan Pengadilan Negeri Yogyakarta tanggal 10 Oktober 2013, Nomor 160 / PDT.G / 2012 / PN.Yk.dapat dipertahankan dalam Peradilan Tingkat Banding dan oleh karenanya haruslah dikuatkan

Dengan demikian pada peristiwa yang terjadi pada kedua kasus yang sudah diuraikan diatas terdapat pembatalan akta PPAT yang terjadi dikarenakan sama - sama mengacu pada perbuatan melawan hukum pada Pasal 1365 KUHPedata yang dilakukan oleh para pejabat yang berwenang untu membuat akta yaitu PPAT. Pada kedua kasus tersebut diatas penulis sependapat dengan majelis hakim yang memutuskan perkara tersebut dikarenan memenuhi unsur perbuatan melawan hukum dan dapat untuk dibatalkan akta PPAT tersebut.

\section{Konsep Pengaturan Kedepan Terhadap Pembatalan Akta Pejabat Pembuat Akta}

\section{Tanah}

\section{a. Makna keadilan bagi pejabat pembuat akta tanah}

Terkait keadilan pada pebatalan akta PPAT bisa disamakan dengan nilai- nilai dasar sosial, keadilan yang lengkap bukan hanya mencapai kebahagiaan untuk diri sendiri, tetapi juga kebahagian orang lain, keadilan yang dimaknai sebagai tindakan pemenuhan kebahagiaan diri sendiri dan orang lain, adalah keadilan sebagai sebuah nilai-nilai, keadilan dan tata nilai dalam hal ini adalah sama tetapi memiliki esensi yang berbeda, sebagai hubungan seseorang dengan orang lain adalah keadilan, namun sebagai suatu sikap khusus tanpa kualifikasi adalah nilai, ketidakadilan dalam 
hubungan sosial terkait erat dengan keserakahan sebagai ciri utama tindakan yang tidak fair ${ }^{24}$

Keadilan menurut Aristoteles menguraikan bahwa keadilan adalah persamaan, dan ketidakadilan adalah ketidaksamaan, ketidakadilan terjadi jika satu orang memperoleh lebih dari yang lainnya dalam hubungan yang dibuat secara sederajat. Sedangkan menurut John Rawls ialah bahwa yang menyebabkan ketidakadilan adalah situsi sosial sehingga perlu diperiksa kembali mana prinsip - prinsip keadilan yang dapat digunakan untuk membentuk situasi masyarakat yang baik. ${ }^{25}$

\section{b. Makna kepastian hukum pejabat pembuat akta tanah}

Menurut Utrecht, kepastian hukum mengandung dua pengertian, yaitu pertama, adanya aturan yang bersifat umum membuat individu mengetahui perbuatan apa yang boleh atau tidak boleh dilakukan, dan kedua, berupa keamanan hukum bagi individu dari kesewenangan pemerintah karena dengan adanya aturan yang bersifat umum itu individu dapat mengetahui apa saja yang boleh dibebankan atau dilakukan oleh Negara terhadap individu. ${ }^{26}$

Terkait pada kepastian hukum pejabat pembuat akta tanah maka konsep kepastian hukum ini untuk memberikan perlindugan pada PPAT, perlindungan hukum ini untuk mencapai kepastian hukum bagi PPAT, maka konsep pada kepastian hukum pada PPAT ini ialah suatu bentuk perlindungan hukum yang diberikan kepada setiap PPAT atas suatu tindakan melindungi atau memberikan pertolongan dalam bidang hukum agar seseorang mendapatkan keadilan dan kepastian hukum dari perbuatan kesewenang-wenangan dari pihak yang tidak bertanggung jawab. ${ }^{27}$

\section{c. Makna kemanfaatan hukum pejabat pembuat akta tanah}

Bentham menggariskan arah dan visi hukum dari perspektif psikologis yang mendalam tentang prinsip utilitarisme. Bentham menulis: "Alam telah menempatkan manusia di bawah kekuasaan dua tuan, yaitu ketidaksenangan dan kesenangan." Yang

\footnotetext{
${ }^{24}$ Ibid, hlm 33

25 Ibid,

26 Riduan Syahrani, Rangkuman Intisari Ilmu Hukum, (Bandung : Penerbit Citra Aditya Bakti, 1999). hlm. 23

27 Herlien Budiono, Kontrak Minyak dan Gas Bumi Berazas Keadilan dan Kepastian Hukum, (Jakarta: Fikahati Aneska, 2009). hlm. 23
} 
harus kita lakukan dan yang akan kita perbuat, semuanya ditujukan dan ditetapkan dalam rangka keduanya. Standar baik dan buruk, serta mata rantai sebab dan akibat, juga terkait erat dengan kedua hal itu. ${ }^{28}$

Pada kaitanyan kemanfataan bagi PPAT ialah ia telah memberikan manfaat hukum pagi setiap produknya yang ia buat yaitu akta, akta yang dibuat PPAT sudah mempunyai nilai kemanfaatan bagi setiap individu yang membuat akta pada PPAT, kemanfaatannya ialah mempunyai nilai ekonomis yang melekat pada akta dan objek yang ada dalam akat PPAT tersebut, lalu penulis mempunyai konsep berfikir bahwa pembatalan akta yang dibuat oleh PPAT bahwa hukum bertujuan untuk "the greatest happiness of the greatest number" aliran utilitarisme dianggap sebagai aliran yang meletakkan kemanfaatan sebagai tujuan utama hukum, kemanfaatan disini diartikan sebagai kebahagiaan (happiness). Pada konteks ini apakah hukum dapat memberikan kebahagiaan kepada manusia atau tidak.

Teori utilitas Bentham mengatakan bahwa hukuman dapat dibenarkan jika pelaksanaannya mengkristalkan dua efek utama yakni: ${ }^{29}$ 1). Konsekuensi hukuman itu ialah mencegah agar di masa depan kejahatan terhukum tidak akan terulang lagi; 2). Hukuman itu memberikan rasa puas bagi si korban maupun orang lain. Ciri khas hukuman ini bersifat preventif ke masa depan agar orang tidak lagi mengulangi perbuatannya dan pemenuhan rasa senang orang-orang yang terkait kasus hukum tersebut.

\section{KESIMPULAN}

Pertama, Kualifikasi akta otentik ditinjaun pada Pasal 1868 KUHPerdata yang menjelaskan bahwa akta otentik yang pada bentuk yang ditentukan oleh undangundang, serta memenuhi syarat formal pada akta PPAT didalam syarat sahnya perjanjian 1320 KUHPerdata. Dengan demikian akta PPAT dapat dilihat pada keontetikannya akta tersebut dikarenakan dibuat oleh pejabat yang berwenang. Berdasarkan teori kepastian hukum, adanya ketentuan tersebut merupakan wujud kepastian hukum yang diberikan oleh KUHPerdata; Kedua, Akta PPAT yang dibatalkan oleh pengadilan, Berdasarkan Pasal 1870 KUHPerdata maka ada salah satu aspek yang

\footnotetext{
${ }^{28}$ Frederikus Fios, Keadilan Hukum Jeremy Bentham Dan Relevansinya Bagi Praktik Hukum Kontemporer (Jakarta ; Jurnal, Jurusan Psikologi, Faculty of Humanities, BINUS University Vol 4, ) hlm 303

${ }^{29}$ Ibid, hlm 304
}

198 HUKMY|Jurnal Hukum 
menyebabkan cacatnya akta, sehingga akta tersebut dapat menjadi akta yang terdegradasi atau akta dibawah tangan, bahkan menjadi batal demi hukum. Dengan demikian berdasarkan teori kepastian hukum pembatalan pada akta PPAT disebabkan oleh kesalahan atau kelalaian para pihak yang saling mengikatkan diri pada akta tersebut memenuhi unsur perbuatan melawan hukum, adanya ketentuan tersebut merupakan wujud kepastian hukum yang diberikan oleh KUHPerdata; dan Ketiga, Konsep pengaturan kedepan terhadap pembatalan akta pejabat pembuat akta tanah, berdasarkan pada tujuan hukum yaitu pada makna keadilan, kepastian serta kemanfaatan hukum bagi PPAT, maka pada teori kepastian hukum bahwa untuk menentukan suatu ketentuan hukum sudah baik, haruslah memenuhi tiga syarat yaitu pertama, secara filosofi dapat menciptakan keadilan, kedua, secara sosiologis dapat menciptakan kemanfaatan dan ketiga, adalah secara yuridis dapat menciptakan kepastian hukum, adanya ketentuan tersebut merupakan wujud kepastian hukum yang diberikan oleh KUHPerdata

Berdasarkan penjelasan permasalahan dalam pembahasan di atas, maka dapat diberikan saran sebagai berikut: Pertama, Pemerintah Indonesia perlu adanya sosialisai dan penyuluhan hukum terkait pada Notari/PPAT yang berwenang untuk membuat akta otentik utnuk lebih berhati- hati dalam melaksanakan tugas dan kewajibanya agar produk hukumnya dikemudian hari tidak ada bentuk pelanggaran hukum serta melakukan perbuatan melawan hukum. Kedua, Kementerian Hukum dan Ham , perlu dilakukan bentuk kepastian hukum pada PPAT yang saat menjalankan tugasnya akta yang dibuat dibatalkan oleh pengadilan dikarenakan akta otentik merupakan sebagai nilai pembuktian yang sempurna. Dan Ketiga, Organisasi PPAT perlu adanya upaya yang jelas bagi Notaris/PPAT dalam menjalankan tugas dan kewajibannya dikarenakan selama ini UUJN dan Peraturan terkait PPAT masih belum bisa memenuhi kebutuhan hukum bagi Notaris /PPAT.

\section{DAFTAR PUSTAKA}

Frederikus Fios, Keadilan Hukum Jeremy Bentham Dan Relevansinya Bagi Praktik Hukum Kontemporer, (Jakarta ; Jurnal, Jurusan Psikologi, Faculty of Humanities, BINUS University Vol 4 
Habib Adjie, Kebatalan Dan Pembatalan Akta Notaris, (Bandung, PT Refika Aditama, 2011

Herlien Budiono, Asas Keseimbangan Bagi Hukum Perjanjian Indonesia (Hukum Perjanjian Berlandaskan Asas-Asas Wigati Indonesia), PT.Citra Aditya Bakti, Bandung, 2006

Herlien Budiono, Kumpulan Tulisan Hukum Perdata DI Bidang Kenotariatan, (Bandung ; Citra Aditya Bakti, 2012 ), hlm 34

Herlien Budiono, Kontrak Minyak dan Gas Bumi Berazas Keadilan dan Kepastian Hukum, Jakarta: Fikahati Aneska, 2009

Herowati Poesoko, Parate Executi obyek Hak Tanggungan (inkonsistensi, konflik norma dan kesatuan penalaran dalam UUHT), Yogjakarta : Laksbang Pressindo, 2008

Herry Susanto, Peranan Notaris Dalam Menciptakan Kepatutan Dalam Berkontrak, Yogyakarta, FH UII Press ,2010

Ima Erlie Yuana, Ruang Lingkup Kenotariatan, Bandung ; Pradnya Paramitha

Liliana Tedjosaputro, Etika Profesi Notaris dalam Penegakan Hukum Pidana,Yogyakarta, PT. Bayu Indra Grafika, 2005

Paulus Effendi Lotulung, Perlindungan Hukum bagi Notaris Selaku Pejabat Umum dalam Menjalankan Tugasnya, Bandung, Pradnya Paramita, 2003

Peter Mahmud Marzuki, Penelitian Hukum, Edisi Revisi Cetakan ke 9, Jakarta : Kencana Prenada Media Group 2014

Riduan Syahrani, Rangkuman Intisari Ilmu Hukum, Bandung : Penerbit Citra Aditya Bakti, 1999

Ridwan Indra R.A. Ragam Perjanjian di Indonesia. Jakarta: CV. Trisula, 1996.

Subekti, Hukum Acara Perdata, Bandung ; Bina Cipta, 1989

Sudikno Mertokusumo, Mengenal Hukum Suatu Pengantar), Yogyakarta, Liberty, 2005.

Syahrul Ibad, The Development Village Government In Synergity Of The Implementation In Law No. 6/2014, Jurnal Politico Vol. 20 No. 2 September 2020 Page: 113-124, DOI: https://doi.org/10.32528/politico.v20i2.3638

\section{Peraturan Perundang - Undangan}

Burgelijk Wetbook (BW)

Undang - Undang Nomor No 5 Tahun 1960 Tentang Peraturan Dasar Pokok - Pokok Agraria

Undang-Undang Nomor 2 Tahun 2014 Tentang Perubahan Atas Undang-Undang Nomor 30 Tahun 2004 Tentang Jabatan Notaris.

Peraturan Menteri Negara Agraria/ Kepala Badan Pertanahan Nasional Nomor 3 Tahun 1997 Tentang Ketentuan Pelaksanaan Peraturan Pemerintah Nomor 24 Tahun 1997 Tentang Pendaftaran Tanah.

Peraturan Pemerintah Republik Indonesia Nomor 24 Tahun 2016 Tentang Perubahan Atas Peraturan Pemerintah Nomor 37 Tahun 1998 Tentang Peraturan Jabatan Pejabat Pembuat Akta Tanah. 